\title{
Seroprevalence for brucellosis and leptospirosis in dogs from Belém and Castanhal, State of Pará, Brazil
}

\author{
Giselle Souza da PAZ ${ }^{*}$, Katarine de Souza ROCHA ${ }^{2}$, Michele de Souza LIMA², Ediene Moura JORGE², \\ José Carlos Figueiredo PANTOJA ${ }^{1}$, Carla Cristina Guimarães de MORAES ${ }^{2}$, Helio LANGONI ${ }^{1}$ \\ 1 Universidade Estadual Paulista "Júlio de Mesquita Filho". Faculdade de Medicina Veterinária e Zootecnia, Departamento de Higiene Veterinária e Saúde pública. Distrito de Rubião \\ Junior, S/N, CEP: 18618-970, Botucatu, SP, Brasil. \\ 2 Universidade Federal do Pará. Instituto de Medicina Veterinária. Rod. BR 316, km 62, S/N, Bairro Saudade, CEP: 68740-970, Castanhal, PA, Brasil. \\ * Autor correspondente: giselle.spaz@gmail.com
}

\section{ABSTRACT}

Brucellosis and leptospirosis are widely spread bacterial infections and dogs are the most important source of infection and reservoir for diseases. Dogs can disseminate the agents in the environment and transmit them to humans and/or other animals. The objective of this study was assess the occurrence of reactive to antibodies anti-Leptospira spp., Brucella canis and B. abortus in Belém and Castanhal, State of Pará, Amazon, Brazil. A total of 156 samples were randomly collected in the city of Belém and 158 samples in Castanhal. The anti-B. canis antibodies research was performed by Agar Gel Immunodiffusion (AGID) with and without 2-mercaptoethanol serum treatment (AGID-2ME). To assess the anti-B. abortus antibodies, the technique of Fast Seroagglutination with buffered acidified plate antigen (BAPAT) was used. For anti-Leptospira spp. antibodies research, the Microscopic Agglutination Technique (MAT) was used. No animal reacted to Brucella abortus and one animal was reactive to $B$. canis at the AGID, but it was negative to the AGID-2ME test. Seventeen percent of dogs (47/274) presented anti-Leptospira spp. antibodies, with prevalence of serovar Canicola. The dogs from Belém and Castanhal are not source of infection for $B$. abortus and B. canis, however, they are reservoirs for different serovars of Leptospira spp.

KEYWORDS: Leptospira spp., Brucella spp., domestic canids, Serology

\section{Soroprevalência para brucelose e leptospirose em cães de Belém e Castanhal, Pará, Brasil}

\section{RESUMO}

Brucelose e leptospirose são enfermidades bacterianas amplamente disseminadas e o cão é importante fonte de infecção e reservatório para ambas, podendo eliminar o agente no meio ambiente, e transmiti-lo para humanos e/ou outros animais. $\mathrm{O}$ presente estudo teve como objetivo pesquisar a ocorrência de cães reagentes para anticorpos contra Leptospira spp., Brucella canis e B. abortus em Belém e Castanhal, Pará, Amazônia, Brasil. Foram colhidas de forma aleatória 156 amostras no município de Belém e 158 amostras em Castanhal. A pesquisa de anticorpos anti- $B$. canis foi realizada pela técnica de Imunodifusão em Gel de Ágar (IDGA) com e sem tratamento do soro com 2-mercaptoetanol (IDGA-2ME) e para pesquisa de anticorpos anti- $B$. abortus foi utilizada a técnica de Soroaglutinação Rápida com antígeno acidificado tamponado (AAT). Para pesquisa de anticorpos contra-Leptospira spp. utilizou-se a Técnica de Aglutinação Microscópica (MAT). Nenhum animal reagiu para Brucella abortus e um animal foi reagente para B. canis na IDGA, porém foi negativo na IDGA-2ME. Dezessete por cento dos cães (47/274) apresentaram anticorpos contra-Leptospira spp., com predominância do sorovar Canicola. Os cães de Belém e Castanhal não são fontes de infecção para $B$. abortus e $B$. canis, no entanto são reservatórios de diferentes sorovares de Leptospira spp.

PALAVRAS-CHAVE: Leptospira spp., Brucella spp., Canídeos domésticos, Sorologia 


\section{INTRODUCTION}

The relation between the human population and the animals has leads to an increase in the dissemination of infectious agents (Brasil 2010). This makes, necessary a larger control of the zoonoses. Dogs are the source of infection and reservoir of bacterial diseases like brucellosis and leptospirosis, and they can disseminate infectious agents contaminating the environment or the humans directly (Greene 2011). They are considered occupational diseases for veterinarians and other professionals involved in the breeding and handling of this species (Mandell et al. 2005).

Canine brucellosis was initially diagnosed by Carmichael et al. (1966) in the United States and in Brazil by Godoy et al. (1977) in Minas Gerais. Thereafter, results from other researchers evidenced its occurrence both by Brucella suis (Gomes et al. 1972; Correa et al. 1984), and by B. canis (Mólnar et al. 2001; Moraes et al. 2002).

Leptospirosis is one of the most disseminated and globally important zoonoses. Its incidence is mainly increased in summer due to the rainfalls and floods in urban areas (Pappas et al. 2008). Several serovars are involved in the canine infection, but the most frequent ones are the Icterohaemorrhagiae and the Canicola, this last one adapted to the canine species (Fontaine 2013).

Serological investigations performed in the Amazon region by Aguiar et al (2005) revealed reactant dogs to Brucella canis and B. abortus in the city of Monte Negro, state of Rondônia. In Belém, Pará, Carvalho et al. (2000) examined $236 \mathrm{dogs}$ and found $45.3 \%$ of reactant animals to B. canis and $5.9 \%$ to B. abortus. With regards to the research of Leptospira spp. in dogs, Aguiar et al (2007) detected $27.3 \%$ of reactant animals, with predominance of serovars Autumnalis, Pyrogenes, Canicola and Shermani in Monte Negro, Rondônia. In Oriximiná, Pará, the research of antiLeptospira spp. antibodies was performed in 185 dogs with $18.3 \%$ of positivity, and Canicola, Icterohaemorrhagiae and Copenhageni were the most frequent serovars, (Lilenbaum et al. 2000).

The study of leptospirosis and canine brucellosis in the Amazon region is important so that it is possible assessing how much the canine species has been contributing to the maintenance and dissemination of these bacteria in the environment, since the region provides an excellent weather for the survival and multiplication of its agents. Thus, the objective of the present work is assessing the frequency of seropositive dogs for leptospirosis and brucellosis in the cities of Belém and Castanhal (Pará) and associating the results with variables such as: sex, pedigree, age, access to streets, animal's provenance, mating and abortion history, access to farms, and ingestion of non-pasteurized milk.

\section{MATERIALS AND METHODS}

The study was performed in the cities of Belém (latitude: $01^{\circ} 27^{\prime} 21^{\prime \prime} \mathrm{S}$ and longitude: 48 30' 16" W) and Castanhal

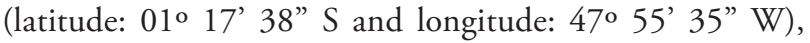
located at the Metropolitan Mesoregion of Belém, State of Pará. There is no canine census in these cities and the mean of dogs, according to the antirabic vaccination in the years of 2013 was of 182 thousand dogs in the city of Belém and 32 thousand in Castanhal.

A total of 156 samples were randomly collected in the city of Belém and 158 samples in Castanhal through visits to community shelters (89 dogs), Center of Zoonoses Control (CCZ) of Belém (32 dogs), commercial kennel (22 dogs) and domiciles (168 dogs). Therefore, totalizing 311 serum samples of healthy dogs from different ages. The person responsible by the dog was invited to participate in the research voluntarily.

For the research of anti-Brucella canis and anti-B. abortus antibodies, 311 samples were used and for research of antiLeptospira spp antibodies 274 samples. The blood samples were collected by jugular or cephalic venipuncture, with the aid of sterile needles $(30 \times 8)$, in sterile anticoagulant vacuum tubes (Vaccutainer $^{\odot}$ ). After the retraction of the clot, the samples were centrifuged for ten minutes at $1614 \mathrm{~g}$, conditioned in plastic microtubes (Eppendorf ${ }^{\circledR}$ ) and stored in temperature of $-20^{\circ} \mathrm{C}$ until the performance of the serological tests.

The research for anti-B. canis antibodies was performed by the Agar Gel Immunodiffusion test (AGID) with or without treatment with 2-mercaptoethanol (AGID-2ME). For the detection of anti- $B$. abortus antibodies, the selection of the serum was made by the proof of fast seroagglutination in plaque using the buffered acidified antigen (BAA). Both tests were performed at the Laboratory of Zoonoses and Public Health of the Federal University of Pará, Campus of Castanhal.

The investigation of anti-Leptospira spp antibodies was performed by the Microscopic Agglutination Test (MAT), performed at the Service of Zoonoses Diagnosis of the Universidade Estadual Paulista, Campus of Botucatu. A total de 25 serovars (Australis, Bratislava, Autumnalis, Butembo, Castellonis, Bataviae, Canicola, Whitcombi, Cynopteri, Djasiman, Sentot, Grippotyphosa, Hebdomadis, Copenhageni, Icterohaemorrhagiae, Javanica, Panamá, Pomona, Pyrogenes, Hardjo, Wolffi, Shermani, Tarassovi, Andamana and Patoc) were used. They were kept in a medium of Ellinghausen-McCullough-Johnson-Harris (EMJH) culture at a temperature of $28{ }^{\circ} \mathrm{C}$. Initially, the selection of the serum was performed and those with agglutination of $50 \%$ or more, in other words, $50 \%$ of agglutinated leptospiras were considered reactant and submitted to the titration procedure. The cutting point used was the dilution of 1:100 (WHO 2003). 
The animals' owners respond to a questionnaire on access to streets, age, pedigree, and sex of the animals. The animals' data were grouped regarding the age and they were divided in three age groups, dogs with age up to three years old, dogs with more than three years old and up to seven years old, and animals with more than seven years old. With regards to the place, they were grouped as dogs from collective shelters for animals, animals from the Center of Zoonoses Control, from commercial kennels, and animals from domiciles. Another variable analyzed was the frequency that dogs had access to the streets, and classified as: always (they had daily free access to the streets), sometimes (dogs which only accessed the streets with leash followed by its owner) and never (animals that were always inside home and/or backyard). With regards to pedigree they were classified in defined pedigree, in other words, animals with pedigree and without defined pedigree (SRD). In the questionnaire, questions related to the ways of transmitting brucellosis in dogs were made (history of mating and abortions, access to rural properties and ingestion of raw milk, not boiled or pasteurized), but these data were not analyzed since animals positive to $B$. canis and B. abotus were not found.

For performing the statistic analysis, frequency distribution to the variables (sex, pedigree, age, place of living and access to streets) were used and the Chi-squared test was used for comparing the proportion of serum-positive animals among the classes of possible risk factors studied. Subsequently, a logistic regression model (PROC GLIMMIX; SAS Institute, 2011) was used for estimating the Odds Ratio of a serumpositive animal among the classes of factors previously associated to the positivity. (PROC FREQ; SAS Institute, 2011). The Odds Ratio is a measure of association used to estimate the chances of an event to occur, between categories of a factor being studied. The numerator of the ratio is the probability of an event to occur and the denominator is the complement of this probability, such that the sum of the probabilities equals 1 .

\section{RESULTS}

The 311 animals were negative for $B$. abortus at the fast serum-agglutination proof. With respect to the research for anti-B. canis antibodies, one animal was reactant to the AGID and non-reactant to the AGID-2ME. With regards to the research of anti-Leptospira spp. antibodies, $17.15 \%$ of positivity was observed. The predominant serovars were Canicola (27\%), Patoc (20\%), Icterohaemorrhagiae (14\%) and Copenhageni (11\%), with predominant titer of 100 and 200 and co-agglutination in three samples we found response to more than one sorovar.

There was significant association between infection and the variables 'access to streets' and 'place where the animal live'. The dogs that had frequent access to the streets had 13.5 (IC 95\% $=1.5-125.0)$ times more chances of infection than the animals with limited access to the streets. The chance of infection in animals coming from the Center of Zoonoses Control was 4.0 (IC 95\% = 1.41-11.0) times higher than in the ones coming from community shelters. There was no statistical association between infection and the variables: city, sex, pedigree, and age (Table 1).

\section{DISCUSSION}

The low prevalence of anti- $B$. abortus antibodies in both cities studied was observed. Similar results were observed in other regions of the country (Porto et al. 2008; Zanetti et al. 2011; Silva et al. 2012). From the dogs used in the study $99 \%$ came from urban area and from these ones, only $0.07 \%$ had access to rural properties anytime in life, therefore, being less prone to infection by B. abortus. According to Forbes (1990), dogs from rural environment are more susceptible to infection by $B$. abortus, mainly in areas where there is presence of bovine species. Contaminate fresh milk is an important source of contamination of brucellosis to men and other animals, however, only $2.9 \%$ of the dogs ingested non-pasteurized milk.

Table 1. Risk factors for seropositivity of leptospirosis in dogs from the cities of Belém and Castanhal. 2009 - 2010.

\begin{tabular}{|c|c|c|c|c|}
\hline Variables & Total & Positive, N (\%) & P-Value & Odds Ratio (IC 95\%) \\
\hline City & & & 0.92 & \\
\hline Belém & 130 & $22(16.9)$ & & \\
\hline Castanhal & 144 & $25(17.4)$ & & \\
\hline Place & & & 0.04 & \\
\hline Shelther & 88 & $9(10.2)$ & & \\
\hline $\mathrm{CCZ}^{1}$ & 31 & $10(32.3)$ & & $4.0(1.41-11.0)$ \\
\hline Kennel & 20 & $03(15.0)$ & & \\
\hline Domicile & 135 & $25(18.5)$ & & \\
\hline Sex & & & 0.85 & \\
\hline Females & 178 & $30(16.8)$ & & \\
\hline Males & 96 & $17(17.7)$ & & \\
\hline Pedigree & & & 0.20 & \\
\hline Pedigree & 60 & 07 (11.7) & & \\
\hline SRD & 214 & $40(18.7)$ & & \\
\hline Age (years) & & & 0.12 & \\
\hline $0-3$ & 108 & $13(12.0)$ & & \\
\hline $3-7$ & 112 & $25(22.3)$ & & \\
\hline$>7$ & 54 & $09(16.7)$ & & \\
\hline $\begin{array}{l}\text { Access to the } \\
\text { streets }\end{array}$ & & & 0.02 & \\
\hline sometimes & 32 & $01(3.1)$ & & \\
\hline never & 220 & $39(17.7)$ & & \\
\hline always $^{2}$ & 22 & $07(31.8)$ & & $13.5(1.5-125.0)$ \\
\hline
\end{tabular}

${ }^{1}$ comparison with the category "shelter"; ${ }^{2}$ comparison with the category "sometimes"; CCZ -Center of Zoonoses Control; SRD - No Defined Pedigree 
Despite the animals are not reactants to anti- $B$. abortus antibodies, reactant dogs have been already detected in other researches in the State of Pará. Carvalho et al. (2000) detected $5.93 \%$ of reactant animals to B. abortus using ELISAc. Also Lopes et al. (1999), studying serum samples coming from animals and human species in the same State detected reactant dogs $(4.3 \%)$ for B. abortus by the ELISA technique. These researches were performed more than one decade ago, indicating that this disease is under control in the studied region.

In the present study, an animal was reactant to $B$. canis at the AGID, but when submitted to 2-Mercaptoethanol AGID it was negative, similar to researches performed in São João da Boa Vista (São Paulo) and Monte Negro (Rondônia) (Malek dos Reis et al. 2008; Aguiar et al. 2005). The use of 2-mercaptoethanol has the objective of reducing the falsepositive reactions and non-specific reactions in serological tests since they break IgM immunoglobulines (Moraes et al. 2002), being of vital importance in confirmation tests.

Studies performed in the Amazon region Santana et al. (2013) in Araguaína, Tocantins and Carvalho et al. (2000) in Belém, Pará showed high prevalence for anti-B. canis antibodies by the AGID. The use of Agar Gel Immunodiffusion (AGID), although it is considered a good test for diagnosis of canine brucellosis, must be used with caution due to its low sensitivity, and it may be unable to detect recent infections (Keid et al. 2004).

The negativity to $B$. canis in the present study can be justified by the fact that previous studies in the region were performed more than ten years ago, and management and breeding techniques have improved, since $77.8 \%$ of the dogs had no access to the streets, and despite $94 \%$ of the animals are not castrated, only $25 \%$ had intercourse anytime in their reproductive life. Besides, all the animals were healthy and only $0.03 \%$ of the females had abortion history.

The prevalence of anti-Lepospira spp. antibodies in the cities of Castanhal and Belém was $17.15 \%$, similar to the results found in Campina Grande-PB, Botucatu-SP, Umuarama-PR, and North of Pantanal (Lopes et al. 2005; Batista et al.; 2005; Jorge et al. 2011; Dreer et al. 2013). The State of Pará, despite having precarious basic sanitation infrastructure when compared to the states of São Paulo and Paraná, the prevalence of anti-Leptospira spp. antibodies was similar in different regions of Brazil, showing that leptospirosis is still a serious public health problem in the country and dogs can be source of infection for other animals and for humans.

The serovar Canicola was more frequent in the present study, since this serovar is adapted to the canine species, the animals can be infected, and symptomless disseminate the bacteria (Goldstein 2010). Fact that makes difficult to control the disease, since asymptomatic animals are difficult to be diagnosed because the owner does not realize that the animal is infected, and the dog become a source of infection in the leptospiruria phase.

Serovar Patoc, belonging to the Seramanga serogroup, was the second one in occurrence despite the species L. biflexa being considered apatogenic and saprophyte, it can act as antigenic stimulation in the animal organism and, sometimes, trigger crossed reaction with other pathogenic serovars (Myers 1976). Other studies showed serological response to this serovar as the one of Silva et al. (2010) in dogs, equines, swine, ovine, bovines and opossums in the city of Jaboticabal, São Paulo, and by Machiori Filho et al. (2002) as the most frequent one in boars created in semiconfining systems in Paraná and Sáo Paulo, showing that this serovar is present in the environment and it can cause false-positive results if misinterpreted by veterinarians or other health professionals.

The serovar Icterohaemorrhagiae is the most pathogenic to human beings (Brasil 2008) and it was the third one in frequency in the present study. Such fact brings concern to public health, by the fact that these cities have high rainfall intensity with constant floods, associated to the presence of rodents which are the main reservoirs of the serovar, and which contaminate the environment, and the water putting humans and animals in risk at moments of flood, which are common in this region.

There was no statistical difference between reactant animals from the cities of Belém and Castanhal, with $22 \%$ and $25 \%$ of seropositive animals, respectively, corroborating the results of Lilenbaum et al. (2000) that observed $18.4 \%$ of the reactant dogs in the city of Oriximiná in the same State, with predominance of serovars Icterohaemorrhagiae, Copenhageni and Canicola, similar to the present study.

With regards to pedigree, sex, age, there was no significant difference, different from what Modolo et al. (2006) suggested, that male dogs without defined pedigree present higher infection risk. Also, these results are different from those reported by Tuemmers et al. (2013) that observed higher prevalence in dogs with age from five to eight years. The animals of the present study are exposed to the same risks of acquiring the infection by Leptospira spp. apart from sex, pedigree or age, therefore, being recommended prophylactic measures such as vaccination for all the dogs of the region.

It was also observed that dogs coming from the Center of Zoonoses Control (CZZ) are more susceptible to infection than the ones living in shelters, kennels and domiciles. Since the CCZ daily receives wander animals, directly from different points of the city, with different life histories and since they are agglomerated in small cages, consequently, the risk of leptospiric infection is increased, as well as for other pathogens. 
It was also verified significant association between infection and the variable access to streets, so that the animals with frequent access present higher risk factor for infection, being 13.5 times higher comparing with dogs with limited access to the streets. This fact represents a serious public health problem, since dogs have the instinct of demarking territory with their urine, which increases the chances of infection by the disseminated leptospiras through the urine, because once infected, they can become chronic carriers. Additionally, the constant rainfalls and the high humidity of the air in the cities of Belém and Castanhal, make the environment propitious to the survival of leptospiras, and the dog becomes an important reservoir for the maintenance of this zoonosis cycle in the region (Tuemmers et al. 2013).

\section{CONCLUSION}

Despite the absence of reactant dogs to B. abortus and $B$. canis in the region, these animals can act as reservoirs of different Leptospiras serovars. The most frequent serovars were the Canicola, Patoc, Icterohaemorrhagiae and Copenhageni. Dogs coming from the Center of Zoonoses Control and with access to the streets present a higher risk fact for the leptospiric infection. The vaccination of dogs with the most frequent serovars in the region would be the most indicated prophylactic measure for decreasing the risks of transmission of this disease in canines, and consequently, to the human beings.

\section{REFERENCES}

Aguiar, D.M.; Cavalcante, G.T.; Vasconcellos, S.A.; Megid, J.; Salgado, V.R.; Cruz, T.F. et al. 2005. Ocorrência de anticorpos anti-Brucella abortus e anti-Brucella canis em cães rurais e urbanos do Município de Monte Negro, Rondônia, Brasil. Ciência Rural, 35: 1216-1219.

Aguiar, D.M.; Cavalcante, G.T.; Marvulo, M.F.V.; Silva, J.C.R.; Pinter, A.; Vasconcellos, S.A. 2007. Fatores de risco associados à ocorrência de anticorpos anti-Leptospira spp. em cães do município de Monte Negro, Rondônia, Amazônia Ocidental Brasileira. Arquivo Brasileiro de Medicina Veterinária e Zootecnia, 59: 70-76.

Batista, C.S.A.; Alves, C.J.; Azevedo, S.S.; Vasconcellos, S.A.; Morais, Z.M.; Clementino, I.J.; Alves, F.A.L.; Lima, F.S.; Araújo Neto, J.O. 2005. Soroprevalência e fatores de risco para a leptospirose em cães de Campina Grande, Paraíba. Arquivo Brasileiro de Medicina Veterinária e Zootecnia, 57: 179-185.

Brasil, 2008. Ministério da Saúde. Secretaria de Vigilância em Saúde. Departamento de Vigilância Epidemiológica. Doenças Infecciosas e Parasitárias: Guia de Bolso. $7^{\mathrm{a}}$ ed. Brasília, 372p.

Brasil, 2010. Situação epidemiológica das zoonoses de interesse para a saúde pública, 10: 1-16. (www.saude.gov.br/svs). Acesso em: 04/03/2014.

Carmichael, L.E. 1966. Abortion in 200 Beagles. Journal of the American Veterinary Medical Association, 149:1126
Carvalho, M.R.; Molnár, L.; Molnár, E.; Dias, H.L.; Lima, E.S.C. 2000. Ocorrência da Brucella canis e Brucella abortus em cáes criados no Estado do Pará. Revista de Ciências Agrárias. 34: 69-76.

Correa, W.M.; Correa, C.N.H.; Iamaguti, P. 1984. Brucelose canina por Brucella suis 1 atípica. Arquivo Brasileiro de Medicina Veterinária e Zootecnia, 36: 397-405.

Dreer, M.K.P.; Gonçalves, D.D.; Caetano, I.C.S.; Gerônimo, E.; Menegas, P.H.; Bergo, D. et al. 2013. Toxoplasmosis, leptospirosis and brucellosis in stray dogs housed at the shelter in Umuarama municipality, Paraná, Brazil. Journal of Venomous Animals and Toxins including Tropical Diseases, 19: 1-5.

Fontaine, A.G. 2013. Diagnosis algorithm for leptospirosis in dogs: disease and vaccination effects on the serological results. Veterinary Record, 172: 502-506.

Forbes, L.B.B. 1990. Abortus infection in 14 farm dogs. Journal of the American Veterinary Medical Association, 196: 911-916, 1990.

Godoy, A.M.; Peres, J.N.; Barg, N. 1977. Isolamento de Brucella canis, em Minas gerais, Brasil. Arquivos da Escola de Veterinária da Universidade Federal de Minas Gerais, 29: 35-42.

Gomes, O.G.; Portugal, M.A.S.C.; Giorgi, W.; França, E.N. 1972. Brucella suis Biotype I. Infeccion in a dog. Arquivos do Instituto Biológico, 39: 251-255.

Goldstein, R.E. 2010. Canine Leptospirosis. Veterinary Clinics of North America: Small Animal Practice, 40: 1091-1101.

Greene, C.E. 2011. Infectious Diseases- of the dog and cat. $4^{\mathrm{a}}$ ed. St Louis, Elsevier, 1376p.

Jorge, R.S.P.; Ferreira, F.; Ferreira Neto, J.S.; Vasconcellos, S.A.; Lima, E.S.; Morais, Z.M. et al. 2011. Exposure of free-ranging wild carnivores, horses and domestic dogs to Leptospira spp. in the northern Pantanal, Brazil. Memórias do Instituto Oswaldo Cruz, 106: 441-444.

Keid, L.B.; Soares, R.M.; Morais, Z.M.; Richtzenhain, L.J.; Vasconcellos, S.A. 2004. Brucella spp. isolation from dogs from commercial breeding kennels in São Paulo State, Brazil. Brazilian Journal of Microbiology, 35:161-166.

Lilenbaum, W.; Rodrigues, F.; Barboza, F. 2000. Aglutininas antileptospiras em caninos do município amazônico de Oriximiná-Pará, Brasil. Revista Brasileira de Ciência Veterinária, 7: 133-135.

Lopes, C.F.A. et al. 1999. Avaliação soroepidemiológica da brucelose em animais e humanos procedentes da zona bragantina no estado do Pará - Brasil. In: Aguiar, D.M.; Cavalcante, G.T; Vasconcellos, S.A.; Megid, J.; Salgado, V.R.; Cruz, T.F. et al. 2005. Ocorrência de anticorpos anti-Brucella abortus e antiBrucella canis em cáes rurais e urbanos do Município de Monte Negro, Rondônia, Brasil. Ciência Rural, 35: 1216-1219.

Lopes, A.L.S.; Silva, W.B.; Padovani, C.R.; Langoni, H.; Modolo, J.R. 2005. Frequência sorológica antileptospírica em cáes: sua correlação com roedores e fatores ambientais, em área territorial urbana. Arquivos do Instituto Biológico, 72: 289-296.

Malek dos Reis, C.B.; Hoffmann, R.C.; Santos, R.S.; Turri R.J.G.; Oriani, M.R.G. 2008. Pesquisa de anticorpos anti-Brucella canis e anti-Brucella abortus em cães errantes da cidade de São João da 
Boa Vista, Estado de São Paulo, Brasil (2002-2003). Brazilian Journal of Veterinary Research and Animal Science, 45: 32-34.

Mandell, G.L.; Bennet, J.E.; Dolin, R. 2005. Principles and Practice of Infectious Diseases. 6a ed.: Elsevier, Philadelfia, 3662p.

Marchiori Filho, M.; Girio, R.J.S.; Lui, J.F.; Mathias, L.A.; Brasil, A.T.R. 2002. Estudo sorológico para leptospirose em populaçóes de diferentes grupos genéticos de javalis (Sus scrofa scrofa, Linnaeus, 1758) dos estados de São Paulo e Paraná. Arquivos do Instituto Biológico, 69:9-15.

Modolo, J.R.; Langoni, H.; Padovani, C.R.; Shimabukuro, F.H.; Mendonça, A.O.; Victoria, C. et al. 2006. Investigaçáo soroepidemiológico de leptospirose canina na área territorial urbana de Botucatu, São Paulo, Brasil. Brazilian Journal of Veterinary Research and Animal Science, 43: 598-604.

Molnár, L.; Molnár, E.; Carvalho, M. 2001. Capacidades de algumas provas sorológicas no diagnóstico da brucelose canina. A Hora Veterinária, 21:45-47.

Myers, D.M. 1976. Serological studies and isolations of serotype Hardjo and Leptospira biflexa strains from horses of Argentina. Journal of Clinical Microbiology, 3: 548-555.

Moraes, C.C.G.; Megid, J.; Souza, L.C.; Crocci, A.J. 2002. Prevalência da brucelose canina na microrregiáo da serra de Botucatu, São Paulo, Brasil. Arquivos do Instituto Biológico, 69: 7-10.

Pappas, G.; Papadimitriou, P.; Siozopoulou, V.; Christou, L.; Akritidis, N. 2008. The globalization of leptospirosis: worldwide incidence trends. International Journal Infectology Diseases, 12: 351-357.

Porto, W.J.N.; Pinheiro Junior, J.W.; Mota, R.A. 2008. Associação entre distúrbios reprodutivos e anticorpos anti-Brucella sp. em cães atendidos em clínicas particulares da cidade de Maceió-AL. Revista Brasileira de Ciência Veterinária, 15: 6-9.
Santana, J.A.; Dorneles, E.M.S.; Jayme,V.S.; Galvão, S.R.; Minharro, S.; Santos, H.; Mathias, L.A.; Dasso, M.G.; Heinemann, M.B.; Lage, A.P. 2013. Risk factors and presence of antibodies to Brucella canis and smooth Brucella in dogs from the municipality of Araguaína, Tocantins, Brazil. Semina: Ciências Agrárias (Online), 34: 2951-2956.

SAS Institute. 2011. SAS/STAT User's Guide. Version 9.3, SAS Institute Inc., Cary, NC.

Silva, F.J.; Mathias, L.A.; Magajevski, F.S.; Werther, K.; Assis, N.A.; Girio, R.J.S. 2010. Anticorpos contra Leptospira spp. em animais domésticos e silvestres presentes no campus universitário da FCAV, UNESP, Jaboticabal/SP. ARS Veterinária, 26: 17-25.

Silva, L.C.; Leuzzi Junior, L.A.; Nassar, J.L.B.; Barca Junior, F.A.; Headley, S.A. et al. 2012. Serological detection of Brucella canis in shelter dogs from Northern Paraná. Semina: Ciências Agrárias, 33: 2391-2396.

Tuemmers, C.; Lüders, C.; Rojas, C.; Serri, M.; Espinoza, R.; Castillo, C. 2013. Prevalencia de leptospirosis en perros vagos capturados en la ciudad de Temuco, 2011. Revista Chilena de Infectologia, 30: 252-257.

WHO, 2003. Human leptospirosis: guidance for diagnosis, surveillance and control. (www.who.int/csr/don/en/WHO_ CDS_CSR_EPH_2002.23.pdf). Acesso em 16/11/2013.

Zanetti, D.F.; Pinto Neto, A.; Silva, A.V.; Martins, L.A. 2011. Detecção de anticorpos anti-Brucella abortus em cães da comunidade Porto Camargo-Pr. Arquivo de Ciência Veterinária e Zoologia, 14: 41-44.

Recebido em 05/09/2014

Aceito em 24/02/2015 